\title{
Apoptosis in human hepatocellular carcinoma and in liver cell dysplasia is correlated with p53 protein immunoreactivity
}

\author{
M Zhao, A Zimmermann
}

\begin{abstract}
Aims-To investigate the prevalence of apoptosis in human hepatocellular carcinomas (HCC) of different types and grades and in liver cell dysplasia, and to test whether the apoptotic rate is correlated with the p53 protein status.

Methods-37 HCC and 66 six liver samples with liver cell dysplasia were analysed for apoptosis using in situ DNA end labelling (ISEL), and for p53 protein expression by immunohistochemistry. In HCCs, proliferative activity was quantitatively assessed using proliferating cell nuclear antigen labelling.

Results-The apoptotic index in HCC as based on ISEL ranged from 0.1 to 13.5 per 1000 cells analysed and was not related to type or grade. No nuclear staining was observed in multinuclear tumour cells. There was a significant correlation between the apoptotic rate and both the proliferative activity and p53 protein reactivity. In liver samples containing p53 protein positive liver cell dysplasia cells, there was a significantly higher apoptotic rate of these cells.
\end{abstract}

Conclusions-Apoptosis is detectable in HCC, and is not related to type and grade. There is a highly significant positive correlation between the apoptotic rate in HCC and both the proliferative activity and p53 protein expression. A similar phenomenon occurs for putative cancer precursors. The findings support the role of p53 in regulating apoptosis in preneoplastic and neoplastic liver lesions. (F Clin Pathol 1997;50:394-400)

Keywords: apoptosis; hepatocellular carcinoma; liver cell dysplasia; $\mathrm{p} 53$ protein

Institute of Pathology of the University, Berne, Switzerland M Zhao

A Zimmermann

Correspondence to: Arthur Zimmermann MD, Professor of Pathology, Institute of Pathology of the University, Murtenstrasse 31, CH-3010 Berne, Switzerland.

Accepted for publication 22 January 1997
As in many renewing normal tissues and in neoplastic disorders, growth of hepatocellular carcinoma (HCC) is determined by the difference between cell proliferation and cell death. Among factors operational in tissue cell loss, apoptosis-as a form of programmed cell death-holds a particularly important place. Apoptosis is genetically programmed and is now recognised as a widespread phenomenon that counterbalances proliferation to preserve tissue homeostasis. Whereas mitotic figures in tumours are easily detectable, assessment of apoptotic cells in tissue sections using cytomorphological criteria is difficult, because of

\section{Abbreviations}

HCC - hepatocellular carcinoma

ISEL_-in situ DNA nick end labelling

LI-labelling index

LLCDo-large liver cell dysplasia with nuclear hypochromasia

LLCDe-large liver cell dysplasia with nuclear hyperchromasia

PCNA - proliferating cell nuclear antigen

SLCD—small liver cell dysplasia

SRLC-simple regenerating liver cells/ hepatocytes

TdT-terminal deoxynucleotidyl transferase

the frequently disrupted architecture in tumours and the presence of several different cell types. Furthermore, the detection and quantification of apoptosis is hampered by the fact that cell shrinkage, nuclear condensation, and chromatin fragmentation usually occur only during advanced stages of the process, and the half life of frankly apoptotic cells in tissues is thought to be in the region of several hours at most. ${ }^{1}$ The reproducible identification of apoptotic cells in malignant tumours of the liver is important in so far as programmed cell death also occurs in later stages of carcinoma development. ${ }^{2}$ There is evidence that apoptosis does not occur at random in the liver. During regression of hyperplasia, non-proliferating hepatocytes seem to be preferred for apoptosis, and cells in putative preneoplastic foci of rat liver show a much higher rate of apoptosis than normal hepatocytes. ${ }^{3-6}$ Furthermore, after initiation in the liver, many initiated cells may undergo apoptosis and never develop into preneoplastic foci, so that apoptosis appears to determine the efficiency of initiation; early preneoplastic foci in the promotion stage also show enhanced states of apoptosis. ${ }^{6}{ }^{7}$ Based on these earlier observations and the difficulties arising from the employment of conventional methods only, it is necessary to identify apoptotic cells in an early stage of this active pathway. ${ }^{8}$ One method of achieving this is the use of in situ DNA end labelling, ${ }^{10}$ which exploits the presence of DNA breaks that occur in cells undergoing apoptosis. The in situ DNA nick end labelling method (ISEL) has previously been employed for studying liver disease, for instance allograft rejection and end stage liver disease, ${ }^{11}$ and for the assessment of apoptosis in HCC. ${ }^{12}$ In the present retrospective 
study, we systematically studied the apoptotic rate in HCC of different types and grades and in liver cell dysplasia by use of ISEL. We also analysed the correlation of the apoptotic rate in HCC with their proliferative status and their p53 protein immunoreactivity.

\section{Methods}

MATERIAL FOR HISTOLOGY

Biopsy and operation specimens from $37 \mathrm{Chi}$ nese patients with cirrhosis and HCC, and from 66 Chinese patients with cirrhosis but without HCC were retrospectively analysed. The selection criterion for these cases was the presence of liver cell dysplasia within cirrhotic nodules, and this was identified in a set of 1748 liver biopsies observed between 1957 and 1988 in a Chinese centre. The material analysed did not contain nodules of atypical adenomatous hyperplasia. ${ }^{13}$ Biopsies of human tonsils, and of livers showing no relevant histological change (staging biopsies without evidence of malignant disease), obtained from 13 patients covering a similar age range served as normal controls.

Tissue samples were fixed in $10 \%$ formaldehyde solution, dehydrated, and embedded in paraffin. Formalin fixation before embedding was less than 30 hours throughout, which is important for ISEL staining. Sections were stained with haematoxylin and eosin.

\section{HISTOLOGICAL CLASSIFICATION OF HCC AND} LIVER CELL DYSPLASIA

HCC were classified according to published criteria. ${ }^{14}{ }^{15}$ Grading of HCC was performed following guidelines previously reported. ${ }^{16}$ As a working formulation, dysplastic and regenerating hepatocytes were classified into four groups on the basis of morphological features in comparison with normal hepatocytes. Four classes of lesion were distinguished: simple regenerating liver cells/hepatocytes (SRLC); large liver cell dysplasia with nuclear hypochromasia (LLCDo); large liver cell dysplasia with nuclear hyperchromasia (LLCDe); and small liver cell dysplasia (SLCD). Identification and detection of these lesion groups were performed according to previously published criteria $^{17}{ }^{18}$ :

$S R L C$ are hepatocytes which are smaller than normal hepatocytes, but with apparently normal nuclear size. The main difference between SRLC and normal hepatocytes is the tendency of the former to form small foci or clusters with nuclear crowding within cirrhotic nodules, where they usually occur in the periphery.

$L L C D o$ are large hepatocytes with a large nucleus and one or several prominent nucleoli, frequently showing an abundant eosinophilic or clear cytoplasm. LLCDo usually occur in clusters and occupy a part of a cirrhotic nodule, but may form entire nodules as well.

$L L C D e$ are cells which have some features in common with LLCDo, but they usually show markedly hyperchromatic or even polymorphous nuclei. Like LLCDo, LLCDe may form clusters of cells of entire nodules.
SLCD are cells which, when compared with LLCD cells, have a distinctly smaller cell and nuclear size. In contrast to SRLC, the cytoplasm is basophilic and the nuclei are hyperchromatic and may show atypia. Cells of SLCD are in most instances located in peripheral parts of cirrhotic nodules, where they form clusters or small foci, as previously reported, ${ }^{18}$ but they may also form entire nodules.

IMMUNOHISTOCHEMISTRY

Proliferating cell nuclear antigen (PCNA) immunostaining ${ }^{19-22}$ was performed using the APAAP procedure. Tissue sections were deparaffinised and rehydrated (Tris- $\mathrm{NaCl}$ buffer: $0.1 \%$ Tris and $1 \% \mathrm{NaCl}, \mathrm{pH} 7.4$, Merck). The sections were then exposed to $3 \%$ bovine serum albumin (BSA; Merck) in Tris-NaCl buffer with $0.1 \mathrm{ml} / \mathrm{ml}$ normal horse serum and $0.1 \% \mathrm{NaN}_{3}$ for 45 minutes at room temperature. Afterwards, the preparations were incubated with a primary mouse monoclonal antibody directed against PCNA (DakoPCNA, PC 10) for one hour. A dilution of 1:50 in Tris- $\mathrm{NaCl}$ buffer containing $0.1 \% \mathrm{NaN}_{3}$ was used. Rabbit antimouse immunoglobulin (Dako) at a dilution of 1:30 and APAAP mouse monoclonal antibody (Dako) at a dilution of 1:50 were applied for 45 minutes each. Following the respective incubations, the sections were rinsed three times in Tris- $\mathrm{NaCl}$ buffer. All incubations were performed in a humidified environment at room temperature. The alkaline phosphatase reaction was run for $20 \mathrm{~min}$ utes in New Fuchsin substrate solution, and the reaction was stopped by rinsing the sections in cold tap water. Finally, the sections were counterstained with haematoxylin (Merck) and mounted with Aquadex (Merck). The primary antibody was substituted with normal mouse serum (Dako) in protein concentration of $0.06 \mathrm{mg} / \mathrm{ml}$ Tris- $\mathrm{NaCl}$ buffer for negative control sections, and all other steps were performed for these preparations. As a positive control an HCC preparation strongly expressing PCNA was processed in parallel to each incubation step.

For p53 immunohistochemistry, the following antibodies were employed: CM-1 (Medac Diagnostica, dilution 1:200); PAb-1801 (Oncogene Sciences, dilution 1:20); PAb-240 (Oncogene Sciences, dilution 1:10); and PAb-421 (Oncogene Sciences, dilution 1:5); DO-7 (Dako dilution 1:100). Antibody $\mathrm{CM}-1$ is raised against recombinant human wild-type p53 protein; antibody PAb-1801 recognises a denaturation resistant epitope in human p53 protein located between amino acid residues 32 and 79, PAb-240 recognises an epitope localised between amino acids 156 and 335, PAb-421 recognises an epitope between amino acids 370 to 378 , and DO-7 recognises an epitope between amino acids 35 to $45 .{ }^{18}$ For PAb-1801, PAb-240, PAb-421, and DO-7, immunostaining was performed using a modified APAAP procedure as given above for PCNA, whereas the p53 CM-1 antibody was assessed by use of a modified avidin-biotin complex (ABC) technique, as previously described in a $\mathrm{p} 53$ study performed by our group. ${ }^{18}$ 
IN SITU DNA END LABELLING (ISEL)

For the in situ visualisation of apoptotic cells, ISEL was used according to a previously published method. ${ }^{9}$

Paraffin sections ( $4 \mu \mathrm{m}$ thick) were affixed to Super Frost/plastic slides (Menzel-Gläser, Germany). Deparaffination was performed by heating the sections for four hours at $58^{\circ} \mathrm{C}$. Hydration was executed by transfering the slides through the following solutions: twice in xylene bath for 10 minutes each, twice in $100 \%$ ethanol for five minutes each, and then for three minutes in $96 \%, 70 \%$, and $35 \%$ ethanol, and three times in double distilled water. Fresh solvents were used in each case, as even traces of impurities may interfere with the reactions. The prepared paraffin sections were then digested by incubation with $5 \mu \mathrm{g} / \mathrm{ml}$ proteinase $\mathrm{K}$ (Sigma) for 20 minutes at room temperature, and washed three times in double distilled water for five minutes each. Peroxidase and DNAses were inactivated by incubating the sections in $2 \% \mathrm{H}_{2} \mathrm{O}_{2}$ for five minutes at room temperature. Afterwards, sections were rinsed with double distilled water three times. The TdT (terminal deoxynucleotidyl transferase; nucleoside-triphosphate: DNA deoxynucleotidyl exotransferase; EC 2.7.7.31) reaction mix (30 mM Trizma base, $\mathrm{pH} 7.2,140 \mathrm{mM}$ sodium cacodylate, $1 \mathrm{M}$ cobalt chloride, TdT enzyme $0.2 \mu \mathrm{M} / \mathrm{ml}$, and digoxygenin conjugated or biotinylated dUTP in ENTP buffer; Boehringer Mannheim, Germany) was added to cover the sections and then incubated in humidified atmosphere at $37^{\circ} \mathrm{C}$ for 60 minutes. The reaction was stopped by transferring the slides to $2 \times$ SSC buffer for 10 minutes (twice) and TB buffer ( $300 \mathrm{mM}$ sodium chloride, $30 \mathrm{mM}$ sodium citrate) for 10 minutes (twice), and sections were incubated 30 minutes in $1 \%$ blocking reagent (Boehringer Mannheim) at room temperature, followed by washing in phosphate buffered saline twice for five minutes. Sections were covered with Extra-avidin alkaline phosphatase (Boehringer Mannheim) at a dilution of $1: 100$ with biotinylated-dUTP, or sheep anti-digoxygenin alkaline phosphatase FAB fragments (Boehringer Mannheim) at a dilution of 1:1000 with alkaline phosphatase conjugated dUTP in the reaction mix for 30 minutes at room temperature. The latter was followed by a 30 minute incubation with APAAP complex (Dako) at a dilution of 1:50. The New Fuchsin substrate solution was used to visualise the reaction, followed by washing three times in phosphate buffer. The substrate reaction was stopped by rinsing the slides in cold tap water and the sections were finally counterstained with haematoxylin and mounted with water soluble mounting medium (Aquadex, Merck). All TdT tailing reaction reagents were purchased from Boehringer Mannheim.

ASSESSMENT OF PROLIFERATION INDEX (BASED ON PCNA STAINING) AND OF APOPTOTIC RATE (BASED ON ISEL)

PCNA and TdT reactive nuclei of dysplastic hepatocytes and HCC cells, respectively, were counted within the areas of interest. The number of positive nuclei per 100 nuclei analysed was used as a PCNA labelling index (PCNA-LI) and a TdT labelling index (TdTLI), respectively. Within $\mathrm{HCC}$, five areas of interest were randomly chosen. For cirrhotic nodules containing liver cell dysplasia, five areas of dysplastic hepatocytes were identified and, within these subsets, cells to be counted were randomly chosen. In each area of HCC and liver cell dysplasia, 1000 cells were analysed. For normal control biopsies, the same strategy was employed.

ASSESSMENT OF P53 PROTEIN IMMUNOREACTIVITY For each of the five anti-p53 protein antibodies employed, immunoreactivity was recorded as either positive or negative, based on the presence or absence of clearly red or brown reaction product for the APPAP and $A B C$ assays, respectively. Neoplastic and nonneoplastic lesions were accepted to be positive when, within and are of interest, at least $10 \%$ of cells were p53 immunoreactive. Pink or beige/ yellowish reaction products were classified as negative.

\section{STATISTICAL ANALYSIS}

For the statistical analysis of differences in apoptosis labelling between groups, KruskalWallis one way and Kolmogorov-Smirnov analyses were employed. A $p$ value of less than 0.05 was accepted as statistically significant.

\section{Results}

HISTOLOGICAL FINDINGS

In table 1, the distribution of types (or subtypes) and grades for $37 \mathrm{HCC}$ is listed. Tumours with a trabecular or mixed (that is, trabecular and pseudoglandular) growth pattern predominated. A compact arrangement of neoplastic cells was observed in three cases, and it formed a component in four heterogeneous tumours. A strong stroma formation, characteristic for sclerosing variants of HCC, was seen in five tumours, and four HCC showed sarcomatoid features, one being of the sarcomatoid type in its entirety. One HCC was rich in tumour cells with macrovesicular fatty change ("fatty HCC"), and a second tumour was partly comprised of this component. Most HCC were of grade 2 or 3 according to Edmondson and Steiner, ${ }^{16}$ and highly differentiated components occurred as part of heterogeneous tumours only; no fibrolamellar HCC was present in this material. All HCC with sarcomatoid features exhibited at least one grade 4 area.

SRLC, LLCDo, LLCDe, and SLCD occurred in cirrhotic livers both with and without associated HCC, and SRLC and dysplastic hepatocytes could coexist within a single cirrhotic nodule. Foci of SRLC, LLCDo, LLCDe, and SLCD were detected in cirrhotic livers without HCC with a prevalence of $33.3 \%, 13.8 \%, 2.7 \%$, and $22.2 \%$, respectively, whereas their prevalence in livers with HCC was $25.7 \%, 30.3 \%, 6.0 \%$, and $39.4 \%$. 
Table 1 Hepatocellular carcinomas (HCC): types, grades, $P C N A-L I$, apoptotic rate (TdT-LI), and p53 immunoreactivity

\begin{tabular}{|c|c|c|c|c|c|}
\hline Case & Type & Grade & $\begin{array}{l}P C N A-L I \\
(\%)\end{array}$ & $\begin{array}{l}T d T-L I \\
(\% \circ)\end{array}$ & $p 53-I R$ \\
\hline 1 & $\mathrm{~T}+\mathrm{SC}$ & $1-2$ & 0 & 0.8 & - \\
\hline 2 & $\mathrm{~T}+\mathrm{P}+\mathrm{SC}$ & $1-2$ & 68 & 4.0 & + \\
\hline 3 & $\mathrm{~T}+\mathrm{SC}$ & $1-2$ & 27 & 4.5 & + \\
\hline 4 & $\mathrm{P}$ & 2 & 15 & 3.0 & - \\
\hline 5 & C & 2 & 40 & 9.5 & + \\
\hline 6 & $\mathrm{~T}$ & 2 & 36 & 5.5 & + \\
\hline 7 & $\mathrm{~T}$ & 2 & 38 & 8.0 & + \\
\hline 8 & $\mathrm{~T}$ & 2 & 58 & 13.5 & + \\
\hline 9 & $\mathrm{~T}$ & 2 & 44 & 0.1 & + \\
\hline 10 & $T$ & 2 & 0 & 0.5 & - \\
\hline 11 & $\mathrm{~T}$ & 2 & 49 & 12.0 & + \\
\hline 12 & $T$ & 2 & 56 & 5.0 & + \\
\hline 13 & $\mathrm{~T}+\mathrm{P}$ & $2-3$ & 57 & 11.5 & + \\
\hline 14 & $\mathbf{P}$ & $2-3$ & 32 & 5.0 & + \\
\hline 15 & C & $2-3$ & 0 & 2.0 & - \\
\hline 16 & C & $2-3$ & 62 & 12.5 & + \\
\hline 17 & $T+C$ & $2-3$ & 0 & 3.0 & - \\
\hline 18 & $T$ & $2-3$ & 20 & 5.0 & + \\
\hline 19 & $\mathrm{P}$ & $2-3$ & 66 & 1.0 & + \\
\hline 20 & $T$ & $2-3$ & 44 & 10.0 & + \\
\hline 21 & $\mathrm{~T}+\mathrm{C}$ & $2-3$ & 0 & 1.0 & - \\
\hline 22 & $\mathbf{P}$ & 3 & 15 & 4.0 & + \\
\hline 23 & $\mathrm{~T}$ & 3 & 21 & 4.0 & + \\
\hline 24 & $\mathrm{~T}$ & 3 & 46 & 11.0 & + \\
\hline 25 & $\mathrm{~T}$ & 3 & 41 & 2.0 & + \\
\hline 26 & $T$ & 3 & 10 & 2.0 & + \\
\hline 27 & $T$ & $3-4$ & 51 & 12.0 & + \\
\hline 28 & $\mathrm{P}+\mathrm{C}+\mathrm{SA}$ & $3-4$ & 20 & 4.0 & + \\
\hline 29 & $\mathrm{~T}$ & $3-4$ & 49 & 12.0 & + \\
\hline 30 & $\mathrm{~T}+\mathrm{SC}$ & $3-4$ & 19 & 5.0 & + \\
\hline 31 & F & 4 & 0 & 2.0 & - \\
\hline 32 & SA & 4 & 37 & 6.5 & + \\
\hline 33 & $\mathrm{SC}+\mathrm{F}$ & 4 & 10 & 2.0 & + \\
\hline 34 & $\mathrm{C}+\mathrm{SA}$ & 4 & 33 & 4.5 & + \\
\hline 35 & $\mathrm{~T}$ & 4 & 0 & 1.0 & - \\
\hline 36 & $\mathrm{~T}$ & 4 & 44 & 10.0 & + \\
\hline 37 & $\mathrm{P}+\mathrm{SA}$ & 4 & 36 & 6.0 & + \\
\hline
\end{tabular}

Type: $\mathrm{T}=$ trabecular; $\mathrm{P}=$ pseudoglandular; $\mathrm{C}=$ compact SC $=$ sclerosing; $\mathrm{SA}=$ sarcomatoid $; \mathrm{F}=$ lipid-rich $\mathrm{HCC}$ ("fatty HCC"). PCNA-LI = PCNA labelling index; TdT$\mathrm{LI}=\mathrm{TdT}$ labelling index; p53-IR = immunoreactivity for $\mathrm{p} 53$ (positive or negative; positivity was accepted when reactivity with at least one out of five anti-p53 antibodies was detected). Grading was performed according to Edmondson and Steiner (four grades). In case of heterogeneity of tumours, more than one subtype of grade may occur.

PROLIFERATIVE ACTIVITY AND P53 PROTEIN EXPRESSION IN HCC AND LIVER CELL DYSPLASIA Proliferative activities of HCC, liver cell dysplasia, and regenerating cells, based on nuclear PCNA reactivity and expressed as PCNA-LI, are shown in tables 1 and 2. No PCNA staining of HCC nuclei was detectable in seven cases (table 1), irrespective of tumour type or tumour grade, but no mitosis and only very few PCNA staining nuclei were observed in adjacent non-neoplastic tissue.

Immunoreactivity for p53 protein in HCC was predominantly nuclear (fig 1). Overall positivity for $\mathrm{p} 53$ protein in $\mathrm{HCC}$ (all five anti-

Table 2 Hepatocellular carcinomas (HCC) and dysplastic/regenerating hepatocytes (LCD): correlation of PCNA and TdT labelling indices (LI) with respect to p53 immunoreactivity

\begin{tabular}{lrllll}
\hline & $n$ & PCNA-LI (\%) & $p$ & $T d T-L I(\%)$ & $p$ \\
\hline A. HCC & 29 & $38.9(2.8)$ & 0.000 & $6.6(0.7)$ & 0.001 \\
p53 positive & 8 & $19.2(1.4)$ & & $1.7(1.3)$ & \\
p53 negative & 18 & $19.2(2.5)$ & 0.024 & $5.1(0.8)$ & 0.001 \\
$\begin{array}{l}\text { B. LCD with HCC } \\
\text { p53 positive }\end{array}$ & 19 & $13.4(2.5)$ & & $1.9(0.8)$ & \\
p53 negative & 46 & $24.9(2.3)$ & 0.000 & $8.6(0.7)$ & 0.0001 \\
$\begin{array}{l}\text { C. LCD without HCC† } \\
\text { p53 positive }\end{array}$ & 20 & $7.5(3.5)$ & & $1.3(1.0)$ & \\
p53 negative & &
\end{tabular}

Values for PCNA-LI (\%) and TdT-LI (\%o) are given as mean (SD).

${ }^{\star}$ Cases with LCD associated with HCC.

†Cases with LCD not associated with HCC. bodies included) was $78.3 \%$, but we observed differences from one antibody to another. The highest yield was found with PAb-1801 (76.5\%), followed by CM-1 (62.1\%), PAb-240 $(16.2 \%)$, PAb-421 (10.8\%), and DO-7 $(10.8 \%)$. Of the $37 \mathrm{HCC}$, three were positive with all five antibodies, two with three, 18 with two, and seven with only one. These differences in reactivity may in part be due to different epitopes recognised by the five antibodies (see above).

For liver cell dysplasia and regenerating cells associated with HCC (all four groups taken together), 18 out of 37 cases were immunoreactive for $\mathrm{p} 53$ protein, SRLC being the most commonly positive $(10 / 37)$. In contrast to the group with $\mathrm{HCC}, \mathrm{p} 53$ protein staining in the group not associated with HCC yielded higher values for both SRLC and liver cell dysplasia $(46 / 66)$. No staining was detected in control liver biopsies.

\section{APOPTOTIC RATE OF HCC}

In human tonsils used as positive controls, strong TdT labelling was seen in phagocytosed nuclear fragments occurring in the cytoplasm of germinal centre macrophages (fig 2). These nuclear fragments (so called tingible bodies) represent structures derived from lymphocytes undergoing apoptosis. In HCC, TdT labelling was clearly seen in the form of a strong reaction product in carcinoma cell nuclei (fig 3). Positive cells sometimes occurred as small clusters. In most situations, reactivity was restricted to nuclei, and no cytoplasmic staining was detectable, but with some exceptions. HCC cells undergoing morphologically visible decay, characterised by loss of cellular integrity and shrinkage of nuclei, sometimes showed staining of both nucleus and cytoplasm. This phenomenon is most probably the result of entry of DNA fragments from a damaged and permeabilised nucleus into the cytoplasm. Furthermore, HCC cells shed from carcinoma tissue which had rounded up to form condensed spherical structures (apoptotic bodies) showed strong overall staining, including the nuclear remnant and the dense cytoplasmic rim. Interestingly, a few polymorphic HCC cells showing no morphological signs of damage had both nuclear and cytoplasmic staining (fig 4). Cytoplasmic staining and staining of nuclear fragments also occurred in areas of typical tumour necrosis (not shown). This phenomenon is most probably due to chromatin decay in necrosis and therefore to the production of numerous reactive DNA sites freely available in the areas involved. Nuclear TdT labelling was detectable in all types of HCC and there was no difference between them (table 1). Cells with positive nuclei did not show any distinct distribution in the sections. Nuclear staining was observed in typical large and granular HCC cells, in cells of intermediate and small size, and in polymorphous cells, but not in multinuclear tumour cells mostly occurring in grade $3 \mathrm{HCC}$. In binucleate tumour cells, one nucleus only was stained in some instances. 


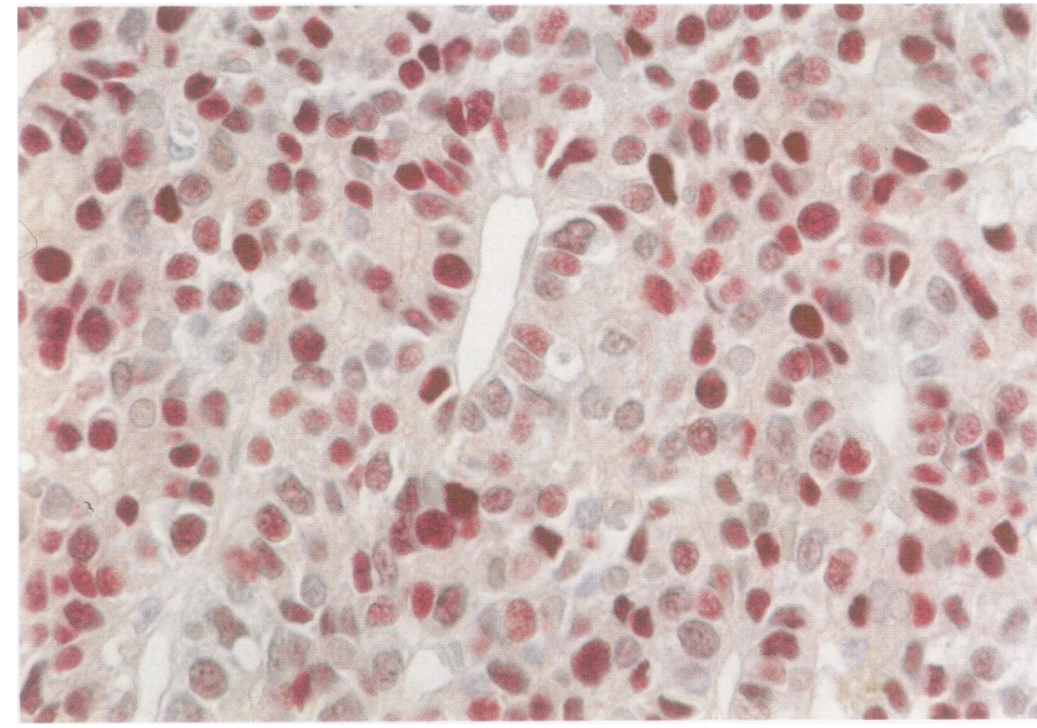

Figure 1 Hepatocellular carcinoma, trabecular and pseudoglandular type, grade 2; 553 protein immunoreactivity is shown as strong staining of nuclei (PAb-1801 antibody; APAAP method; $\times 310$ ).

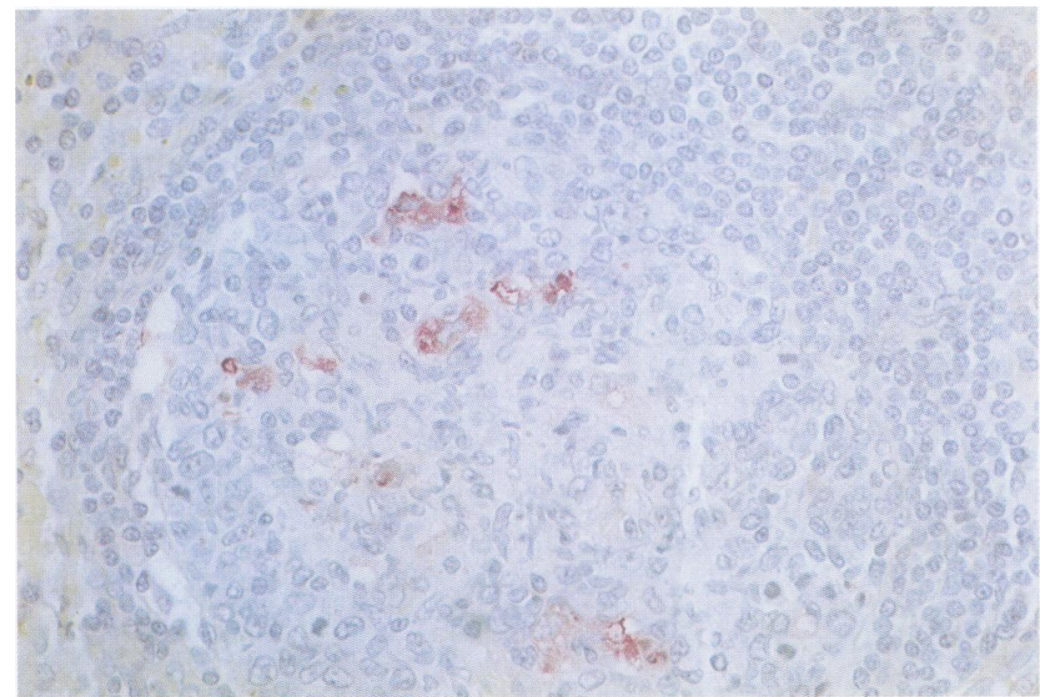

Figure 2 Lymph follicle with germinal centre of a human tonsil, used as positive control for in situ DNA nick end labelling (ISEL). Within the cytoplasm of germinal centre macrophages, phagocytosed nuclear fragments show a strong reaction (ISEL procedure, haematoxylin-eosin counterstain; $\times 250$ ).

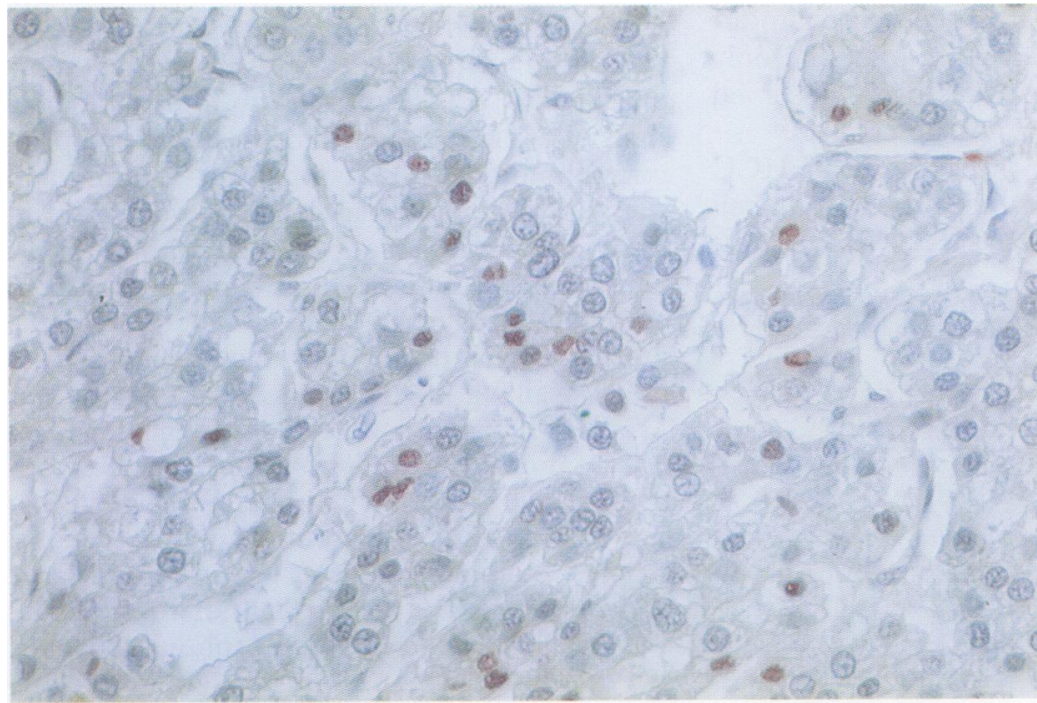

Figure 3 Hepatocellular carcinoma, trabecular type, grade 2. Part of the neoplastic cells harbour nuclei that are immunoreactive after TdT labelling (in situ DNA nick end labelling procedure, haematoxylin-eosin counterstain $; \times 250$ ).
The correlations of TdT-LI and PCNA-LI with respect to $\mathrm{p} 53$ protein immunoreactivity are listed in table 2 . The apoptotic rate and the proliferation rate were significantly higher in p53 positive cases of HCC.

APOPTOTIC RATE OF DYSPLASTIC LIVER CELLS In comparison with HCC, very few nuclei of normal looking hepatocytes were $\mathrm{TdT}$ positive, as in the normal liver tissue used as a control. Among pathological hepatocytes occurring in cirrhotic nodules, nuclear TdT labelling was only observed in SRLC and LLCDo cells, and not in liver cell dysplasia of the SLCD and LLCDe types. Correlations of TdT with PCNA-LI and p53 protein immunoreactivity of liver cell dysplasia cells are given in table 2, with cases subdivided according to whether HCC was present or not.

\section{Discussion}

Apoptosis is recognised as an important function in the cell turnover of normal and neoplastic tissues, ${ }^{123}$ and has been shown to play a significant role in normal liver and in several types of hepatobiliary disease. ${ }^{112425}$ Apoptosis takes place naturally in the liver, albeit at a very low rate. ${ }^{26}$ It has been shown that increased hepatocyte proliferation induced by several factors is normally followed by increased apoptosis. ${ }^{27}$ As both the development and the growth of tumours is determined by the difference between cell proliferation and cell loss, it can be expected that apoptosis is involved in the establishment of liver cancer. In fact, it has been shown that apoptosis occurs in hepatocellular tumours, ${ }^{28}$ that carcinogens exert their carcinogenic effects not only through stimulation of cell replication but also by modulating the incidence of apoptosis, ${ }^{6}$ and that apoptosis occurs in preneoplastic lesions $\mathrm{s}^{26}{ }^{29}$ and in rat hepatoma cells grown in ascites form. ${ }^{31}$ Apoptosis has recently been studied in rat liver tumours by the use of quantitative methods, ${ }^{32} 33$ and in human HCC employing TdT mediated dUTP-biotin nick end labelling. ${ }^{12}$ In the retrospective investigation described here our aim was to analyse apoptosis of human HCC and putative precursor lesions quantitatively, employing a powerful recently established method, in situ DNA nick end labelling (ISEL ${ }^{9}{ }^{10}$ ). ISEL exploits the presence of DNA breaks that occur in cells undergoing apoptosis. By systematically applying this technique we can show that apoptosis occurs in human HCC of different types and grades, apoptotic (TdT) indices ranging from 0.1 to 13.5 per 1000 cells analysed. Staining was confined to HCC nuclei in most situations, as expected. In a previous study, ${ }^{12}$ reactivity had been found in HCC nuclei exclusively. We detected cytoplasmic reactivity in HCC cells showing morphological signs of decay, and assume that this phenomenon is the result of the egress of reactive DNA fragments from damaged and permeabilised nuclei into the cytoplasm. Both nuclear and cytoplasmic staining was also noted in condensed struc- 


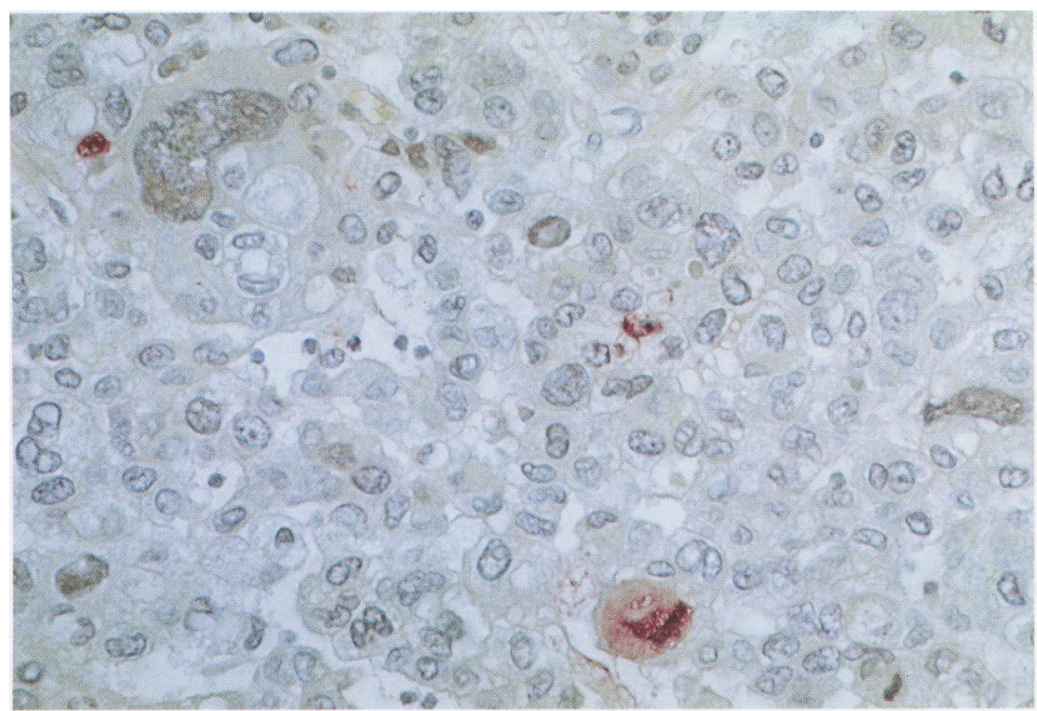

Figure 4 Polymorphic cell hepatocellular carcinoma, grade 3. Nuclear TdT staining is seen in two carcinoma cells (close to centre and upper left corner). In addition a polymorphous cancer cell shows nuclear and cytoplasmic staining (bottom; in situ DNA nick end labelling procedure, haematoxylin-eosin counterstain; $\times 250)$.

tures representing apoptotic bodies. Furthermore, cytoplasmic reactivity was observed in highly polymorphic HCC cells, even though these cells appeared otherwise morphologically intact. However, the morphological detection of apoptosis is difficult, ${ }^{1}$ and large tumour cells with highly abnormal and probably polyploid nuclei may have undergone severe functional damage already, with breakdown of the nuclear membrane barrier. Interestingly, no nuclear staining was observed in multinuclear HCC cells, and in binucleate cells only one nucleus was labelled in some instances. The latter phenomenon may be the result of differential induction or suppression of apoptosis, as studied in somatic cell hybrids. ${ }^{34}$ Previous studies have shown that apoptosis can be induced in cultured hepatocytes with transforming growth factor $\beta,{ }^{35}{ }^{36}$ activin, ${ }^{37}$ tumour necrosis factor $\alpha{ }^{38}$ and microtubule disassembling agents. ${ }^{39}$ The regulation of an apoptotic reaction in liver neoplasms has, however, not yet been elucidated.

No significant correlation was observed between tumour type or grade and proliferative and apoptotic rate, though Hino and coworkers $^{12}$ had observed in their cases of HCC that the proliferation rate and the incidence of apoptosis increased as the differentiation grade was reduced. In contrast, both proliferation (as assessed by PCNA labelling) and apoptotic rate were significantly higher in HCC that were immunoreactive for the p53 protein. It has previously been shown that $\mathrm{p} 53$ overexpression in HCC is correlated with proliferative activity. ${ }^{1840}$ There is, however, also substantial evidence that abnormal expression of negative regulators of the cell cycle, in particular p53 and $\mathrm{Rb}$, is associated with apoptosis. ${ }^{41}$ It is now well established that the overexpression of wild-type p53 can elicit apoptosis in a wide array of cell types, ${ }^{42}$ and experimental systems show convincingly that p53 dependent apoptosis suppresses tumour growth and progression in vivo. ${ }^{43}$ In cultured human hepatoma cells, the anticancer drugs, etoposide and mitomycin $\mathrm{C}$, increased nuclear p53 protein, and this change was followed by apoptosis. ${ }^{45}$ The highly significant correlation between the apoptotic rate and p53 protein immunoreactivity observed in our HCC cases supports these findings. Interestingly, cells suggested to represent putative precursor lesions in a hepatic carcinogenesis pathway, that is, dysplastic hepatocytes, showed the same phenomenon.

From our results we conclude the following: (1) apoptosis as assessed by use of ISEL occurs in human HCC; (2) the apoptotic rate of HCC does not correlate with either type or grade; (3) there is a significant positive correlation between the HCC apoptotic rate and both the proliferative rate and immunoreactivity for $\mathrm{p} 53$ protein; (4) a similar phenomenon occurs for putative precursors cells of HCC; (5) the findings support a significant role for p53 in the regulation of apoptosis in preneoplastic and neoplastic liver lesions.

We gratefully acknowledge the secretarial help of E Müller.

1 Searle J, Harmon BV, Bishop CJ, Kerr JFR. The significance of cell death by apoptosis in hepatobiliary disease. $\mathcal{F}$ Gastroenterol Hepatol 1987;2:77-96.

2 Wyllie AH, Kerr JFR, Currie AR. Cell death: the significance of apoptosis. Int Rev Cytol 1980;68:251-300. significance of apoptosis. Int Rev Cytol 1980;68:251-300.
Bursch W, Lauer B, Timmermann-Trosiener I, Barthel G, 3 Bursch W, Lauer B, Timmermann-Trosiener I, Barthel G,
Schuppler J, Schulte-Hermann R. Controlled cell death (apoptosis) of normal and putative pre-neoplastic cells in rat liver following withdrawal of tumor promoters. Carcinogenesis 1984;5:453-8.

4 Bursch W, Paffe S, Putz B, Barthel G, Schulte-Hermann R. Determination of the length of the histological stages of apoptosis in rat liver and altered hepatic foci. Carcinogenesis 1990;11:847-53.

5 Schulte-Hermann R, Timmermann-Trosiener I, Barthel G, Bursch W. DNA synthesis, apoptosis, and phenotypic expression as determinants of growth of altered foci in rat liver during phenobarbital promotion. Cancer Res 1990; liver during $\mathrm{p}$

6 Schulte-Hermann R, Bursch W, Kraupp-Grasl B, Oberhammer F, Wagner A, Jirtle R. Cell proliferation and apoptosis in normal liver and preneoplastic foci. Environ Health Perspect 1993;101(suppl 5):87-90.

7 Bursch W, Graslkraupp B, Ellinger A, Torok L, Kienzl H, Mullauer L, et al. Active cell death: role in hepatocarcinogenesis and subtypes. Biochem Cell Biol 1995;72:11-12.

8 Allen PD, Bustin SA, Macey MG, Johnston DH, Williams NS, Newland AC Programmed cell death (apoptosis) in immunity and haematological neoplasia. Br f Biomed $S c i$ 1993;50:135-49.

9 Gavrieli Y, Sherman Y, Ben-Sasson SA. Identification of programmed cell death in situ via specific labeling of nuclear DNA fragmentation. F Cell Biol 1992;119:493501

10 Ansari B, Coates PJ, Greenstein BD, Hall PA. In situ end-labelling detects DNA strand breaks in apoptosis and other physiological and pathological states. $\mathcal{f}$ Pathol 1993;170: 1-8.

11 Afford SC, Hübscher S, Strain AJ, Adams DH, Neuberger JM. Apoptosis in the human liver during allograft rejection and end-stage liver disease. $\mathcal{F}$ Pathol 1995;176:373-80.

12 Hino N, Higashi T, Nouso K, Nakatsukasa H, Tsuji T. Apoptosis and proliferation of human hepatocellular carcinoma. Liver 1996;16:123-9.

13 Nakanuma Y, Terada T, Ueda K, Terasaki S, Nonomura A, Matsui O. Adenomatous hyperplasia of the liver as a precancerous lesions. Liver 1993;13:1-9.

14 Gibson JB, Sobin LH. Histological typing of tumors of the liver, biliary tract and pancreas. International histological classification of tumours. 20. Geneva: World Health Organisation, 1978.

15 Nakashima T, Kojiro M. Hepatocellular carcinoma. An atlas of its pathology. Tokyo: Springer, 1987.

16 Edmondson HA, Steiner PE. Primary carcinoma of the liver. A study of 100 cases among 48,900 necropsies. Cancer $1954 ; 7: 462-503$.

17 Zhao M, Zhang NX, Du ZY, Laissue JA, Zimmermann A. Three types of liver cell dysplasia (LCD) in small cirrhotic nodules are distinguishable by karyometry and PCNA labelling, and their features resemble distinct grades of labelling, and their features resemble distinct grades of
hepatocellular carcinoma. Histol Histopathol 1994;9:73-83.

18 Zhao M, Zhang NX, Laissue JA, Zimmermann A. Immunohistochemical analysis of p53 protein overexpression in liver cell dysplasia and in hepatocellular carcinoma. Virchows Arch 1994;424:613-21.

19 Galand P, Degraef C. Cyclin/PCNA immunostaining as an alternative to tritiated thymidine pulse labelling for 
marking $S$ phase cells in paraffin sections from animal and human tissues. Cell Tissue Kinet 1989;22:383-92.

20 Bravo R, MacDonald-Bravo H. Existence of two populations of cyclin/proliferating cell nuclear antigen during the cell cycle: association with DNA replication sites. $\mathcal{F}$ Cell Biol 1987; 105:1549-54.

21 Garcia RL, Coltrera MD, Gown AM. Analysis of proliferative grade using anti- PCNA/cyclin monoclonal antibodies tive grade using anti- PCNA/cyclin monoclonal antibodies

22 Gelb AB, Kamel OW, LeBrun DP, Warnke RA. Estimation of tumor growth fractions in archival formalin-fixed, paraffin-embedded tissues using two anti-PCNA/cyclin monoclonal antibodies. Factors affecting reactivity. $A m \mathcal{F}$ Pathol 1992;141:1453-8.

23 Majno G, Joris I. Apoptosis, oncosis and necrosis. An overview of cell death. Am 7 Pathol 1995;146:3-15.

24 Alison MR, Sarraf CE. Liver cell death: patterns and mechanisms. Gut 1994;35:577-81.

25 Patel T, Gores GJ. Apoptosis and hepatobiliary disease. Hepatology 1995;21:1725-41.

26 Bursch W, Lauer B, Timmermann-Trosiener I, Barthel G Schuppler J, Schulte-Hermann R. Controlled death (apoptosis) of normal and putative pre-neoplastic cells in rat liver following withdrawal of tumor promoters. Carcinogenesis 1984;5:453-8.

27 Columbano A, Ledda-Columbano GM, Coni PP, Faa G Liguori C, Santa Cruz G, et al. Occurrence of cell death (apoptosis) during the involution of liver hyperplasia. $L a b$ Invest 1985;52:670-5.

28 Klion FM, Schaffner F. The ultrastructure of acidophilic "councilman-like" bodies in the liver. Am $\mathcal{F}$ Pathol 1966;48: 755-67.

29 Columbano A, Ledda-Columbana GM, Lee G, Rajalakshmi S, Sarma DSR. Occurrence of cell death (apoptosis) in preneoplastic and neoplastic liver cells. Am 7 Pathol preneoplastic and

30 Zerban H, Radig S, Kopp-Schneider A, Bannasch P. Cell proliferation and cell death (apoptosis) in hepatic preneoplasia and neoplasia are closely related to phenotypic cellular diversity and instability. Carcinogenesis 1994;15:246773.

31 Tessitore L, Costelli P, Sacchi C, Piacentini M, Baccino FM. The role of apop- tosis in growing and stationary rat ascites hepatoma, Yoshida AH-130. F Pathol 1993;171: 301-9.

32 Kong J, Ringer DP. Immunohistochemical assessment of cell proliferation and death levels in well and poorly differentiated rat liver tumors [abstract]. Proc Am Assoc Cancer Res 1995;36:230.
33 Kong J, Ringer DP. Quantitative in situ image analysis of apoptosis in well and poorly differentiated tumors from rat liver. Am F Pathol 1995; 147:1626-32.

34 Gourdeau H, Walker PR. Evidence for trans regulation of apoptosis in intertypic somatic cell hybrids. Mol Cell Biol 1994;14:6125-34.

35 Oberhammer F, Fritsch G, Pavelka M, Froschl G, Tiefenbacher R, Purchio $T$, et al. Induction of apoptosis in cultured hepatocytes and in the regressing liver by transforming growth factor-beta-1 occurs without activa transforming growth factor-beta-1 occurs without activa-
tion of an endonuclease. Toxicol Lett 1992;64/65:701-4.

36 Oberhammer FA, Pavelka M, Sharma S, Tiefenbacher R Purchio AF, Busch W, et al. Induction of apoptosis in cultured hepatocytes and in regressing liver by transforming growth factor-beta 1. Proc Natl Acad Sci USA 1992;89: growth factc

37 Schwall RH, Robbins K, Jardieu P, Chang L, Lai C, Terrel TG. Activin induces cell death in hepatocytes in vivo and vitro. Hepatology 1993;18:347-56.

38 Bour ES, Ward LK, Cornman GA, Isom HC. Tumor necrosis factor-alpha-induced apoptosis in hepatocytes in long-term culture. Am $\mathcal{F}$ Pathol 1996;148:485-95.

39 Tsukidate K, Yamamoto K, Snyder JW, Farber JL. Microtubule antagonists activate programmed cell death (apoptosis) in cultured rat hepatocytes. Am F Pathol 1993;143:91825.

40 Hofmann WJ, Volkmann M, Haag D, Otto G, Galle PR. p53 overexpression in HCC is correlated with the proliferative activity but not with EGF-R expression in the tumors [abstract]. Hepatology 1993;18:185.

41 Gottlieb TM, Oren M. p53 in growth control and neoplasia. Biochim Biophys Acta 1996;1287:77-102.

42 Oren M. Relationship of $\mathrm{p} 53$ to the control of apoptotic dell death. Semin Cancer Biol 1994;5:221-7.

43 Symonds H, Krall L, Remington L, Saenz-Robles M, Lowe S, Jacks T, Van Dyke T. P53-dependent apoptosis suppresses tumor growth and progression in vivo. Cell 1994;78:703-71.

44 Morgenbesser SD, Williams BO, Jacks T, DePino RA. P53dependent apoptosis produced by Rb-deficiency in the developing mouse lens. Nature $1994 ; 371: 72-4$.

45 Kaneko Y, Tsukamoto A. Apoptosis and nuclear levels of p53 protein and proliferating cell nuclear antigen in human hepatoma cells cultured with tumor promoters. Cancer Lett 1995;91:11-17. 